\title{
Effect of temperature increase on cooling systems in livestock farms
}

\author{
V. Valiño ${ }^{1, *}$, A. Perdigones ${ }^{2}$, A. Iglesias ${ }^{3}$, J. L. García ${ }^{1}$ \\ ${ }^{1}$ Dept. of Rural Engineering, ETSI Agronomos; ${ }^{2}$ Dept. of Rural Engineering, EUIT Agricola; and \\ ${ }^{3}$ Dept. of Agricultural Economics and Social Sciences, ETSI Agronomos, Technical University of Madrid, Madrid 28040, Spain
}

\begin{abstract}
We developed a methodology to evaluate the changes in cooling technologies of agricultural buildings derived from different scenarios of global climate change. Four 2080s scenarios were analysed for 6 European locations, using as a case study fattening pig farms and 3 cooling technologies: natural and forced ventilation, and cooling pads. The climate scenarios were constructed as a combination of general circulation models (Had CM2 and ECHAM4) downscaled for Europe with the HIRHAM and RCA3 regional models and driven by the A2 and B2 socio-economic scenarios. A steady-state heat balance model was used for the energy analysis in the livestock farms. The results showed that no changes in cooling technologies are necessary in the Mediterranean Basin; cooling pads were efficient enough for adequate climatisation both in the present and future scenarios. In northern European locations results were different, depending on the future scenario. Most scenarios indicated that cooling pads will be needed in fattening pig farms in the $2080 \mathrm{~s}$, while ventilation is efficient enough in the present scenario. The economic consequences will be important, as the costs associated with cooling pads are much higher than the costs of natural or forced ventilation.
\end{abstract}

KEY WORDS: General circulation models $\cdot$ Downscaling $\cdot$ Cooling systems $\cdot$ Animal houses Resale or republication not permitted without written consent of the publisher

\section{INTRODUCTION}

In the past few years there has been growing concern regarding the effects of global warming on agricultural systems, especially in areas likely to be more seriously affected by rising temperatures, e.g. southern Europe and the Mediterranean Basin (IPCC 2007).

In its Fourth Assessment Report (AR4), the Intergovernmental Panel on Climate Change discussed improved models that enabled best estimates of climate change for different emission scenarios (IPCC 2007). These projections of future climate change from numerical models have existed for a long time, but the PRUDENCE project has provided high resolution change scenarios for Europe at the end of the 21st century (Christensen et al. 2007, Mínguez et al. 2007, Olesen et al. 2007). This modelling process involves 3 steps. (1) Socio-economic emission scenarios provide projections of atmospheric greenhouse gas emissions as a result of changes in population, economic activities and environmental policy. (2) The greenhouse gas concentration is then used in general circulation models (GCMs) to compute resulting global climate variables as a result of this climate forcing; there are a range of GCMs and their resolution varies, but none of the actual GCMs has a resolution higher than $1^{\circ}$ latitude $\times 1^{\circ}$ longitude. (3) To increase resolution, the output from the GCMs can be downscaled by regional climate models (RCMs); this is called dynamical downscaling.

The PESETA project (Ciscar et al. 2009) used the PRUDENCE output to project climate change scenarios at the site level for its agricultural analysis. There are alternative downscaling techniques to produce high-resolution projections. Statistical downscaling is based on observed local climate properties. Finally, stochastic weather generators (WGs) are models which use local weather data to simulate synthetic timeseries of daily weather that are statistically similar to observed weather at the desired local site. Semenov \& Stratonovitch (2010) recently released a WG which includes the predictions from different GCMs used in 
the IPCC AR4 and showed another way of using a multi-model ensemble.

Scenarios are used to represent alternative futures in the event of climate change. Socio-economic scenarios are defined by the IPCC Special Report on Emission Scenarios (SRES; IPCC 2000), representing the potential socio-economic futures that will determine the level of greenhouse gas emissions to the atmosphere. In Scenario family A, economic development is the priority, while in Scenario family B, environmental sustainability considerations are important.

The AR4 states that it is very likely (probability $>66 \%$ ) that high temperature extremes and heat wave events will become more frequent in every emission scenario. An increasing frequency of heat waves would have an adverse effect on crop and livestock productivity over and above the impact of changes in mean variables alone (IPCC 2007, Thornton et. al. 2009). Nienaber \& Hahn (2007) reported the devastating effects of heat waves over the last 3 decades, which caused thousands of animal deaths and important economic losses. High temperatures plus humidity cause heat stress in livestock. A number of authors (e.g. Mader \& Davis 2004, Forman et al. 2008) have assessed the impact of these variables using a temperaturehumidity index (THI) adapted from that employed in a human study (Thom 1959). Hot and humid conditions cause changes in animal behaviour, including reduced feed intake, which could lead to a decline in weight gain, fertility and productivity.

The vulnerability and adaptability of livestock to heat stress varies according to species, genetic potential, life stage and nutritional status (Thornton et al. 2009). For instance, poultry and pigs have a limited ability to dissipate latent heat via the vaporisation of water since they are non-sweating animals (Haeussermann et al. 2007). However, Rötter \& van de Geijn (1999) suggested that the impact of heat stress on intensive livestock production systems (commonly used in poultry and pig raising) might be relatively minor since animal exposure to environmental conditions can be more easily controlled. Nienaber \& Hahn (2007) indicated that housing animals provides the best means of gaining control over environmental variables, although initial investment costs per head are relatively high.

Temperature control inside livestock houses is mainly based on ventilation, both natural and forced. During the winter, the ventilation rate is determined by the requirement of maintaining air quality, while during the summer the removal of excess heat determines the rate (Schauberger et al. 2000, CIGR 2006). Natural ventilation relies on structural openings that allow airflow as a result of convective forces. When increased airflow is needed, mechanical ventilation systems can be used. Tunnel ventilation systems are characterised by a bank of fans at one end of the building and air inlets at the other. The main disadvantage of this cooling method is the axial gradient of temperatures in the direction of the airflow (Willits 2003). During times of greater heat, evaporative cooling methods can be added. The use of fogging and misting inside pen areas is widely used to increase the latent heat content of the air (Haeussermann et al. 2007). Pad cooling, the effects of which are based on evaporation, is commonly used, but initial investment costs can be quite high. Panagakis \& Axaopoulos (2008) showed that fogging could be used to obtain the same results as cooling pads in terms of intensity of heat stress. However, the water requirement was higher.

Few studies have investigated the consequences of climate change on the cooling technologies and energy consumption of agricultural buildings. Some studies have pointed out the change in the heating and cooling requirements of animal houses due to climate change (e.g. Olesen \& Bindi 2002), but no paper deals with this issue in depth. The aim of the present study was to estimate the adequacy of 9 strategies for cooling fattening pig houses at 6 European locations-Madrid (Spain), Athens (Greece), Milan (Italy), Stuttgart (Germany), London (UK), and De Bilt (The Netherlands) using a steady-state balance model.

\section{DATA AND METHODS}

\subsection{Weather data}

The locations for which simulations were carried out were: Madrid $\left(40.4^{\circ} \mathrm{N}, 3.80^{\circ} \mathrm{W}\right.$, altitude $\left.687 \mathrm{~m}\right)$; Athens $\left(38.0^{\circ} \mathrm{N}, 23.7^{\circ} \mathrm{E}, 107 \mathrm{~m}\right)$; Milan $\left(45.5^{\circ} \mathrm{N}, 9.19^{\circ} \mathrm{E}\right.$, $107 \mathrm{~m})$; Stuttgart $\left(48.7^{\circ} \mathrm{N}, 9.2^{\circ} \mathrm{E}, 419 \mathrm{~m}\right)$; London $\left(51.2^{\circ} \mathrm{N}, 0.2^{\circ} \mathrm{W}, 59 \mathrm{~m}\right)$; and De Bilt $\left(52.1^{\circ} \mathrm{N}, 5.2^{\circ} \mathrm{E}\right.$, altitude $2 \mathrm{~m}$ ). The weather data required by the energy model on livestock farms were the following: hourly mean temperature, hourly mean relative humidity and hourly mean solar irradiation on a horizontal surface. In this study, monthly time series of average temperature for the period 1961-1990 were provided by the PESETA project (Ciscar et al. 2009), whereas monthly time series of relative humidity and solar irradiation were obtained from the European Climate Assessment $\&$ Dataset (Klein Tank et al. 2002) and other official climate institutes. Based on these monthly data, values of temperature, relative humidity and solar radiation were calculated for each hour of an average day of each month, following the models described and validated by García et al. (1998) and with the following assumptions. The daily minimum temperature occurs $1 \mathrm{~h}$ before sunrise (for a good adjustment of the curve); 
the daily maximum temperature occurs $2 \mathrm{~h}$ after solar noon; the mean temperature occurs $2 \mathrm{~h}$ after sunset; and the temperature profiles from each mentioned point to the next are described with a sine function ( 3 sine curves for 3 periods each day). The 3 equations must have common values at their common points. Hourly values for solar radiation were generated from daily means by assuming that solar radiation versus time of day follows a sine function, taking into account the length of the day. Finally, hourly values for relative humidity were generated from daily means by assuming that absolute humidity is constant along the day, so relative humidity in each hour can be calculated with the temperature in each hour and the constant value of absolute humidity.

The whole time slice was used (1961-1990), and the output was $24 \mathrm{~h} \mathrm{~d}^{-1}, 1 \mathrm{~d} \mathrm{mo}^{-1}, 12 \mathrm{mo} \mathrm{yr}^{-1}$, for 1 average year. These average periods were representative of the baseline scenario.

For the 2080s climate projections for each site, 4 climate scenarios were used (Table 1). The climate projections at the site level were derived from the downscaled projections of the PESETA project (Ciscar et al. 2009). This involved a combination of GCMs (Had CM2 and ECHAM4) downscaled for Europe with the HIRHAM and RCA3 regional models and driven by the A2 and B2 socio-economic scenarios (SRES). The SRES A2 and B2 were considered since they have been used in many other studies and they cover a wide range of possibilities, avoiding the extreme non-realistic assumptions of the A1 and B1 scenarios in terms of population growth and economic development. Finally, the monthly time series of average temperature at each site and each scenario were obtained by applying the monthly changes in the downscaled scenario temperature compared to baseline, to the time series of observed temperatures at each site. This procedure has been applied in many agricultural studies to derive projections at the site level (Iglesias et al. 2000, Parry et al. 2004). The humidity ratio and solar irradiation were deemed to be constant despite the temperature rise, comparing the baseline with the 2080 scenarios. However, a complete set of calculations was also carried out with an increase in the humidity ratio of $10 \%$ in the 2080 scenario, with respect to the baseline scenario. The hourly values were again obtained with the methodology described (García et al. 1998).

The site results agree with Olesen et al. (2007), who found that the variation in simulated agricultural impacts was smaller across scenarios from RCMs nested in a single GCM than it was across different GCMs or across the different emission scenarios.

\subsection{Steady-state balance model}

Models consisting of dynamic and steady-state heat balances have been developed by several authors in order to represent the internal climate of livestock houses. Cooper et al. (1998) developed a model for estimating the mean inside temperature and ventilation rate in naturally ventilated buildings. This model was also able to calculate the moisture mass balance for buildings with controlled ventilation. Similarly, Schauberger et al. (2000) used a steady-state balance model involving sensible and latent heat exchanges to assess the indoor climate and air quality. Thus, the usefulness of heat balance models has been largely proven in the design of environmental control methods (Schauberger et al. 2000).

In the present study, a steady-state model was developed for modelling the indoor temperature conditions of a fattening pig house with a partially slatted floor. The energy balance is based on the work of Blanes \& Pedersen (2005), who used a sensible heat balance for the calculation of the ventilation flow needed. The main terms of that balance equation were taken, but the effect of the cooling equipment was included by a different term $\left(H_{C}\right)$, taken from Seginer (2002).

The heat balance equation adapted from Blanes \& Pedersen (2005) is Eq. (1), and in this case it is expressed in $\mathrm{W} \mathrm{m}^{-2}$ :

$$
S_{\text {rad }}+S_{\text {trans }}+S_{\text {slurry }}+A^{\prime} S=V_{\text {heat }} h_{s p} \rho\left(T_{i}-T_{o}\right)
$$

where $S_{\text {rad }}$ is the heat gain due to the thermal radiation transmitted through the ceiling. In this study, it was

Table 1. Future (2071-2100) climate scenarios used. Socioeconomic scenarios A2 and B2 from IPCC (2000). GCM: general circulation model; RCM: regional climate model; Temperature change: change in mean annual temperature averaged over Europe

\begin{tabular}{|llccccc|}
\hline & Climate scenario & $\begin{array}{c}\text { SRES } \\
\text { scenario }\end{array}$ & GCM & RCM & $\begin{array}{c}\text { Mean CO } \\
\text { (ppmv) }\end{array}$ & $\begin{array}{c}\text { Temperature } \\
\text { change }\left({ }^{\circ} \mathrm{C}\right)\end{array}$ \\
\hline 1 & HadCM3 A2/ DMI/HIRHAM 2080s & A2 & HadCM3 & DMI/HIRHAM & 709 & 3.1 \\
2 & HadCM3 B2/ DMI/HIRHAM 2080s & B2 & HadCM3 & DMI/HIRHAM & 561 & 2.7 \\
3 & ECHAM4/OPYC3 A2/SMHI/RCA3 2080s & A2 & ECHAM4 & SMHI/RCA3 & 709 & 3.9 \\
4 & ECHAM4/OPYC3 B2/SMHI/RCA3 2080s & B2 & ECHAM4 & SMHI/RCA3 & 561 & 3.3 \\
\hline
\end{tabular}


expressed as $\tau S_{o}\left(\mathrm{~W} \mathrm{~m}^{-2}\right)$, where $S_{o}\left(\mathrm{~W} \mathrm{~m}^{-2}\right)$ is the solar irradiation on the ceiling of the building, and $\tau$ (dimensionless) the proportion of solar radiation transmitted through the cover and used to increase the internal enthalpy.

$S_{\text {trans }}$ is the sensible heat dissipated or gained by convection-conduction through the building cover, and it was considered proportional to the air temperature difference between the outside $\left(T_{o r},{ }^{\circ} \mathrm{C}\right)$ and inside $\left(T_{i},{ }^{\circ} \mathrm{C}\right)$ : $U\left(T_{o}-T_{i}\right)$ in $\mathrm{W} \mathrm{m}^{-2}$. The constant $U\left(\mathrm{~W} \mathrm{~m}^{-2}{ }^{\circ} \mathrm{C}^{-1}\right)$ is the thermal transmission coefficient of the animal house. In the final equation, this term is expressed as heat loss, so it appears in the second member and the air temperature difference changes to $\left(T_{i}-T_{o}\right)$.

$S_{\text {slurry }}$ is the heat gain due to the difference in temperature between the slurry (when it is excreted) and the inside air. This heat gain was considered negligible in this study and it did not appear in the final equation.

$A^{\prime} S$ is the heat gain owing to the sensible animal heat production. $A^{\prime}$ (dimensionless) is a coefficient representing the relative animal activity, and $S\left(\mathrm{~W} \mathrm{~m}^{-2}\right)$ is the corrected sensible animal heat production at house level. These 2 parameters were calculated according to the models described in CIGR (2002) and quoted by Blanes \& Pedersen (2005).

$V_{\text {heat }} h_{s p} \rho\left(T_{i}-T_{o}\right)$ represents the effect of ventilation in the energy balance in Eq. (1). We replaced it with the term $H_{c}\left(\mathrm{~W} \mathrm{~m}^{-2}\right)$ to add the effect of heat losses due to the cooling equipment depending on the given strategy. Thus, $H_{C}$ could take 2 different expressions (Seginer 2002)

Natural and forced ventilation: $H_{c}=V_{\text {heat }} h_{s p} \rho\left(T_{i}-T_{o}\right)(2)$

$$
\text { Pad cooling: } H_{c}=\rho h_{s p} V_{\text {heat }} \eta\left(T_{i}-T_{d}\right)
$$

where $\rho\left(\mathrm{kg} \mathrm{m}^{-3}\right)$ is the air density; $h_{s p}\left(\mathrm{~J} \mathrm{~kg}^{-1}{ }^{\circ} \mathrm{C}^{-1}\right)$ is the specific heat capacity of air at constant pressure; $V_{\text {heat }}$ is the specific ventilation rate $\left(\mathrm{m}^{3}\right.$ [air] $\mathrm{m}^{-2}$ [ground]) calculated from the number of air replacements per hour $N\left(\mathrm{~h}^{-1}\right) ; \eta$ is the cooling pad efficiency (dimensionless; its value depends on the ventilation rate); and $T_{d}\left({ }^{\circ} \mathrm{C}\right)$ is the dew point temperature of the outside air (calculated from the outside relative humidity and the outside air temperature; Singh et al. 2002).

Thus, the final equation of the impact model was Eq. (4), where its first member represented the sensible heat gains of the inside air, while the second represented the sensible heat losses:

$$
\tau S_{o}+A^{\prime} S=U\left(T_{i}-T_{o}\right)+H_{C}
$$

Several coefficients were used in the model. For the proportion of solar irradiance transmitted through the cover, $\tau=0.1$ was chosen; for the coefficient of heat transmission, $U=0.43 \mathrm{~W} \mathrm{~m}^{-2}$ was taken from Blanes \&
Pedersen (2005). Wet pad efficiency values were variable (range 0.64 to $0.95 \%$ ), depending on the specific ventilation rate (Seginer 2002).

The model considered an animal density of $130 \mathrm{~kg}$ of live mass $\mathrm{m}^{-2}$. This value was calculated from the animal reference weight of $85 \mathrm{~kg}$ and the minimum free area of $0.65 \mathrm{~m}^{2}$ dictated by Spanish legislation RD1135-2002 on swine welfare. This animal density value allowed the sensible animal heat production $S$ to be calculated as a heat flux expressed in

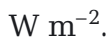

The recommended temperature for fattening pig houses in Spain is $25^{\circ} \mathrm{C}$ in the summer (IDAE 2005) and an on/off differential of $6^{\circ} \mathrm{C}$ should be allowed (thus, the 'on' temperature for cooling is $28^{\circ} \mathrm{C}$ ). The aim of the present simulations was to determine whether the different strategies examined were able to maintain the internal air temperature below $28^{\circ} \mathrm{C}$. For this purpose, the model calculated the heat balance, with $T_{i}=$ $28^{\circ} \mathrm{C}$, and assessed the resulting flux. A positive (negative) value means the cooling strategy is unable (able) to keep the inside temperature below $28^{\circ} \mathrm{C}$. The model was run using Microsoft ${ }^{\circledR}$ Excel software.

\subsection{Cooling equipment}

Cooling strategies with 3 ventilation rates were modelled:

(1) Natural ventilation-(1.1) $N=5 \mathrm{~h}^{-1}$; (1.2) $N=10 \mathrm{~h}^{-1}$ and (1.3) $N=15 \mathrm{~h}^{-1}$.

(2) Forced ventilation-(2.1) $N=20 \mathrm{~h}^{-1}$; (2.2) $N=30 \mathrm{~h}^{-1}$ and (2.3) $N=40 \mathrm{~h}^{-1}$.

(3) Cooling pad system-(3.1) $N=20 \mathrm{~h}^{-1}$; (3.2) $N=30 \mathrm{~h}^{-1}$ and (3.3) $N=40 \mathrm{~h}^{-1}$.

Natural ventilation and forced ventilation were considered to be working permanently throughout the day hours. Pad cooling was controlled with an on/off strategy; it was left to run when the outside air temperature was $>25^{\circ} \mathrm{C}$.

\section{RESULTS AND DISCUSSION}

\subsection{Weather data}

Table 2 shows the main meteorological data for each location in the baseline scenario (1961-1990) and for the 4 future scenarios. The global solar irradiance $S_{o}$ was considered the same for all scenarios. The $\mathrm{RH}_{o}$ values are lower in the 2080s scenarios than in the baseline scenario, since these were recalculated using the 2080 temperatures and with the assumption that the absolute humidity (or humidity ratio) was constant over time. 
Table 2. Estimated yearly mean outside temperature $\left(T_{o}{ }^{\circ} \mathrm{C}\right)$, yearly mean outside relative humidity $\left(R H_{o} \%\right)$ and yearly mean global solar irradiation $\left(S_{o}, \mathrm{~W} \mathrm{~m}^{-2}\right)$ for the baseline (1961-1990) and future scenarios (2080s)

\begin{tabular}{|c|c|c|c|c|c|c|c|c|c|c|c|}
\hline \multirow{2}{*}{ Location } & \multicolumn{2}{|c|}{ Baseline } & \multicolumn{2}{|c|}{ Scenario 1} & \multicolumn{2}{|c|}{ Scenario 2} & \multicolumn{2}{|c|}{ Scenario 3} & \multicolumn{2}{|c|}{ Scenario 4} & \multirow{2}{*}{$S_{o}$} \\
\hline & $T_{o}$ & $R H_{o}$ & $T_{o}$ & $R H_{o}$ & $T_{o}$ & $R H_{o}$ & $T_{o}$ & $R H_{o}$ & & $R H_{o}$ & \\
\hline Madrid & 14.07 & 56.92 & 18.53 & 44.58 & 17.00 & 49.21 & 20.27 & 40.37 & 18.77 & 43.71 & 186.84 \\
\hline Athens & 17.80 & 65.19 & 22.08 & 51.44 & 20.61 & 56.22 & 22.12 & 51.40 & 21.14 & 54.33 & 166.92 \\
\hline Milan & 12.21 & 76.83 & 16.24 & 60.68 & 14.65 & 67.21 & 18.40 & 53.61 & 16.77 & 58.85 & 148.09 \\
\hline Stuttgart & 8.82 & 76.34 & 12.47 & 60.60 & 11.08 & 66.56 & 15.04 & 51.83 & 13.33 & 57.34 & 122.67 \\
\hline London & 9.62 & 80.43 & 12.63 & 68.41 & 11.50 & 73.71 & 14.29 & 61.50 & 13.36 & 65.15 & 110.33 \\
\hline De Bilt & 9.29 & 80.99 & 13.75 & 61.51 & 12.57 & 65.87 & 14.06 & 59.80 & 12.89 & 64.40 & 117.86 \\
\hline
\end{tabular}

\subsection{Cooling strategy simulations}

Table 3 shows the results for the baseline and future scenarios. Given that the summer months were the most critical in terms of cooling requirements, each cell shows the highest value for June-September. The highlighted cells indicate negative values and thus the strategies able to maintain the internal air temperature below $28^{\circ} \mathrm{C}$. The method can supply the energy and water consumption involved in the process, and can easily be adapted to the cooling process of other types of agricultural buildings (any type of livestock farm, greenhouses, agro-industries).

For the baseline scenario, the feasible strategies for the locations in the Mediterranean Basin (Madrid, Milan, Athens) were those that involved cooling pads. Both natural and forced ventilation were insufficient. In fact, higher ventilation rates resulted in higher internal temperatures. For instance, in Madrid, the thermal balance for strategy 1.1 (natural ventilation; $N=5 \mathrm{~h}^{-1}$ ) was 185.6 W m $\mathrm{W}^{-2}$, whereas for strategy 2.3 (forced ventilation; $N=40 \mathrm{~h}^{-1}$ ) it was $273.8 \mathrm{~W} \mathrm{~m}^{-2}$. This finding might be explained by taking into account the outside climate at these locations. During the summer, mean temperatures are usually higher than $28^{\circ} \mathrm{C}$. Thus, the air temperature difference $T_{i}-T_{o}$ changes the direction of the sensible heat flux through the building $\left[U\left(T_{i}-T_{o}\right)\right.$; $\mathrm{W} \mathrm{m}^{-2}$ ] due to convention-conduction forces and the effect of the ventilation system $\left[\rho C Q\left(T_{i}-T_{o}\right) ; \mathrm{W} \mathrm{m}^{-2}\right]$; thus, outside air increases the the ambient internal temperature.

Table 3 shows the heat balance results for the mean $\pm \mathrm{SD}$ of the 4 future scenarios. No change was seen in the suitability of the cooling strategies for the 3 most southerly locations (Madrid, Milan, Athens): cooling pads would be sufficient to keep the indoor conditions

Table 3. Feasibility of cooling techniques in the baseline frame (1961-1990) and future scenarios (2080). Maximum heat flux $\left(\mathrm{W} \mathrm{m}^{-2}\right)$ for the summer months (June-September) calculated by modelling; data are mean \pm SD for the future scenarios. Highlighted cells show when the cooling strategies are feasible (heat balance calculated for a critical temperature of $28^{\circ} \mathrm{C}$ ). Cooling strategies are listed in Section 2.3

\begin{tabular}{|c|c|c|c|c|c|c|c|c|c|}
\hline & \multicolumn{3}{|c|}{-Natural ventilation } & \multicolumn{3}{|c|}{ — Forced ventilation -} & \multicolumn{3}{|c|}{ — Cooling pad system } \\
\hline & 1.1 & 1.2 & 1.3 & 2.1 & 2.2 & 2.3 & 3.1 & 3.2 & 3.3 \\
\hline \multicolumn{10}{|l|}{ Baseline } \\
\hline Madrid & 185.6 & 198.2 & 210.8 & 223.4 & 248.6 & 273.8 & -123.9 & -224.0 & -311.8 \\
\hline Athens & 198.4 & 230.9 & 263.4 & 295.9 & 360.9 & 426.0 & -141.0 & -242.9 & -332.4 \\
\hline Milan & 153.3 & 153.0 & 152.8 & 152.5 & 152.0 & 151.5 & -10.8 & -67.8 & -117.9 \\
\hline Stuttgart & 100.1 & 64.3 & 28.6 & -7.2 & -78.8 & -150.3 & -7.2 & -51.9 & -91.2 \\
\hline London & 83.6 & 37.8 & -8.1 & -53.9 & -143.6 & -233.3 & 6.2 & -31.7 & -64.9 \\
\hline De Bilt & 85.0 & 37.3 & -10.4 & -58.1 & -153.5 & -249.0 & 10.2 & -33.7 & -70.6 \\
\hline \multicolumn{10}{|l|}{ Future } \\
\hline \multirow[t]{2}{*}{ Madrid } & 231.82 & 283.55 & 335.28 & 387.00 & 490.46 & 593.91 & -270.60 & -422.01 & -554.80 \\
\hline & \pm 10.93 & \pm 20.18 & \pm 29.43 & \pm 38.68 & \pm 57.17 & \pm 75.67 & \pm 26.95 & \pm 37.24 & \pm 46.26 \\
\hline \multirow[t]{2}{*}{ Athens } & 231.23 & 292.56 & 355.16 & 417.87 & 544.28 & 670.70 & -214.95 & -345.14 & -459.33 \\
\hline & \pm 8.39 & \pm 16.25 & \pm 23.34 & \pm 30.39 & \pm 43.70 & \pm 57.03 & \pm 11.73 & \pm 16.20 & \pm 20.13 \\
\hline \multirow[t]{2}{*}{ Milan } & 195.62 & 231.19 & 267.28 & 303.40 & 375.64 & 447.87 & -94.92 & -184.10 & -262.31 \\
\hline & \pm 20.41 & \pm 37.67 & \pm 54.58 & \pm 71.49 & \pm 105.32 & \pm 139.16 & \pm 31.88 & \pm 44.04 & \pm 54.71 \\
\hline \multirow[t]{2}{*}{ Stuttgart } & 142.89 & 146.49 & 150.08 & 153.67 & 160.86 & 168.05 & -94.07 & -171.97 & -240.30 \\
\hline & \pm 21.41 & \pm 39.52 & \pm 57.62 & \pm 75.73 & \pm 111.95 & \pm 148.16 & \pm 25.14 & \pm 34.73 & \pm 43.14 \\
\hline \multirow[t]{2}{*}{ London } & 115.53 & 98.84 & 82.96 & 67.08 & 35.31 & 3.54 & -66.20 & -133.03 & -191.63 \\
\hline & \pm 10.60 & \pm 20.46 & \pm 29.84 & \pm 39.21 & \pm 57.97 & \pm 76.72 & \pm 19.72 & \pm 27.65 & \pm 34.72 \\
\hline \multirow[t]{2}{*}{ De Bilt } & 124.44 & 110.12 & 95.79 & 81.47 & 52.82 & 24.17 & -73.58 & -144.06 & -205.87 \\
\hline & \pm 8.95 & \pm 16.52 & \pm 24.09 & \pm 31.65 & \pm 46.79 & \pm 61.93 & \pm 13.31 & \pm 17.22 & \pm 20.80 \\
\hline
\end{tabular}




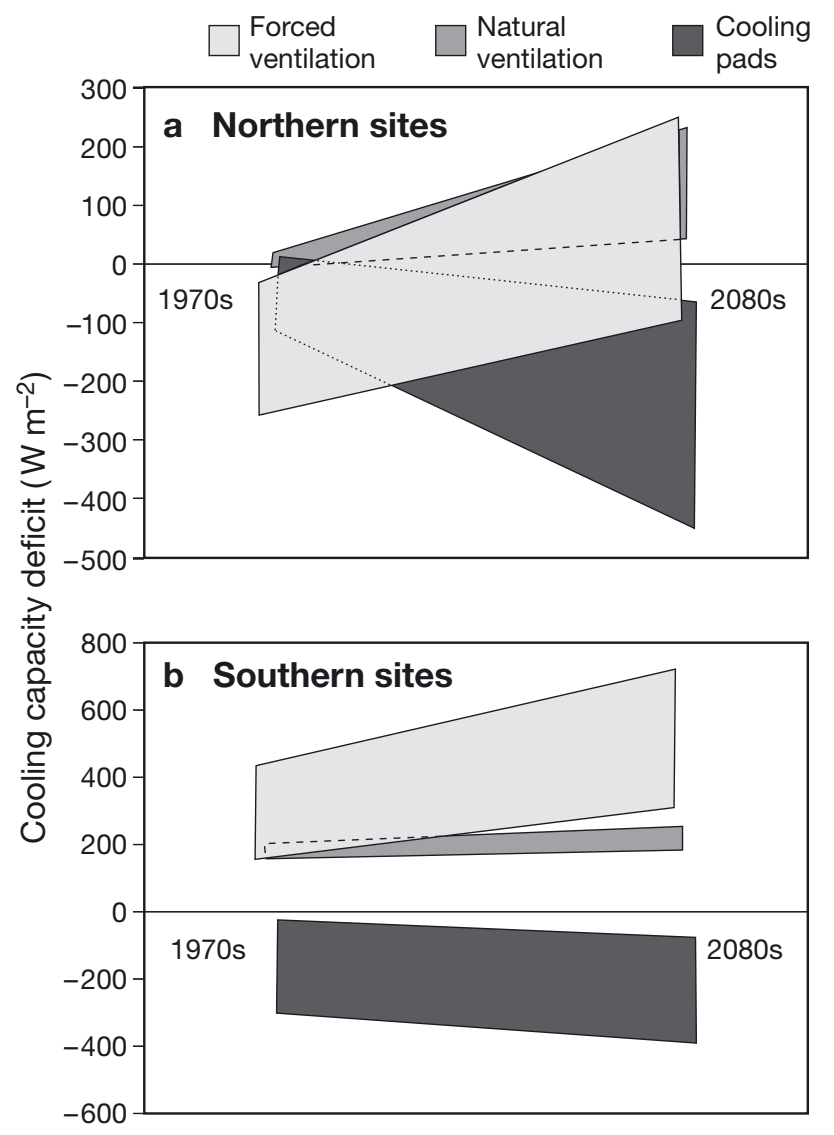

Fig. 1. Cooling capacity deficit $\left(\mathrm{W} \mathrm{m}^{-2}\right)$ in the 4 study scenarios from the baseline up to the period 2070-2100 (2080s) for (a) southern sites and (b) northern sites. The shaded areas represent the ranges due to the different scenarios

below $28^{\circ} \mathrm{C}$. Fig. $1 \mathrm{~b}$ summarises the feasibility of the technologies in the Mediterranean Basin for the 4 future scenarios; no differences among scenarios were found with respect to changes in technologies. Technologies with a positive energy balance (upper part of the diagram) are not able to maintain a suitable temperature, while technologies with a negative energy balance (lower part of the diagram) are able to supply the adequate temperature. Ventilation is not suitable in the baseline or the 2080s scenarios; cooling pads are efficient enough in the baseline and in the 2080s.

However, southern sites will have to run cooling systems longer. The main variation in cost caused by warming at these sites would be the increased electricity costs, which are higher than water costs. Assuming an electrical power ratio of $3 \mathrm{~W} \mathrm{~m}^{-2}$ for the cooling pads, and an electricity cost of $0.1 € \mathrm{~kW} \mathrm{~h}^{-1}$ (García et al. 1998, Willits 2003), the cost would depend on the working hours. The increase in working hours under the different 2080s scenarios with respect to the baseline ranged from 720 to $1860 \mathrm{~h} \mathrm{yr}^{-1}$ in Madrid, from 510 to $1740 \mathrm{~h} \mathrm{yr}^{-1}$ in Milan, and from 840 to $1410 \mathrm{~h} \mathrm{yr}^{-1}$ in
Athens. Thus, the increase in electricity costs would range from 0.22 to $0.56 € \mathrm{~m}^{-2} \mathrm{yr}^{-1}$ in Madrid (an increase from 43 to $111 \%$ with respect to the baseline), from 0.15 to $0.52 € \mathrm{~m}^{-2} \mathrm{yr}^{-1}$ (+35 to $121 \%$ ) in Milan and from 0.25 to $0.42 € \mathrm{~m}^{-2} \mathrm{yr}^{-1}(+36$ to $60 \%)$ in Athens.

According to our experience, the real situation of many fattening pig houses in the present scenario in the Mediterranean Basin is that they are working in suboptimal conditions in summer, working only with ventilation; pigs suffer temperatures $>28^{\circ} \mathrm{C}$ over short periods of time. These periods of sub-optimal conditions cause reductions in livestock fattening. The situation of these sub-optimal farms will get worse in the 2080s (Fig. 1b), with socio-economic consequences: small farms will have to install cooling facilities or disappear.

London and De Bilt are the most northerly locations investigated in the study, and they have the wettest climates. Together with Stuttgart, ventilation at these sites appeared to be able to maintain a temperature $<28^{\circ} \mathrm{C}$ inside the fattening pig facilities, in the baseline scenario. The simulations showed that ventilation had to reach a certain minimum rate to ensure this: $N=$ $15 \mathrm{~h}^{-1}$ for London and De Bilt, and $N=20 \mathrm{~h}^{-1}$ for Stuttgart (Table 3); thus in Stuttgart, forced ventilation is needed. It is remarkable that in the wettest locations (London and De Bilt), the cooling capacity of forced ventilation was higher than that achieved with the cooling pad strategy (for the same air ventilation rate), despite the former being a simpler technology. However, evaporative cooling systems are efficient in dry conditions but not as efficient in wet conditions (Kittas et al. 2003), because the supplied water cannot be efficiently evaporated in wet conditions.

In Future Scenarios 1 and 2, forced ventilation can meet the cooling requirements only in London (Table 3, mean value $3.54 \pm 76.72 \mathrm{~W} \mathrm{~m}^{-2}$ ). In Future Scenarios 3 and 4 , the heat balance results showed that in London, Stuttgart and De Bilt the cooling pad system would be required. The critical point for this change in cooling technologies for northern Europe (in this type of farm) was at a temperature increase of about $3^{\circ} \mathrm{C}$. The economic consequences would be important for this sector, since costs associated with cooling pads are much higher than costs of ventilation.

Costs associated with forced ventilation were about $3.1 € \mathrm{~m}^{-2}$, while costs associated with cooling pads were about $8.8 € \mathrm{~m}^{-2}$ (Romero et al. 2002). Thus, the cost of the change from forced ventilation to cooling pads was $5.7 € \mathrm{~m}^{-2}$; the investment increase for climatisation would be $184 \%$. A pig farm of $5000 \mathrm{~m}^{2}$ and a production of 13500 pigs $\mathrm{yr}^{-1}$ would have to afford an additional investment of $28500 €$.

Fig. 1a shows a summarised view of the 2080s scenarios. Natural ventilation will not be able to maintain the temperature below $28^{\circ} \mathrm{C}$ in any scenario; forced 
Table 4. Results of heat flux simulations considering an increase in the humidity ratio of $10 \%$ : yearly means \pm SD of outside air temperature $\left(T_{0},{ }^{\circ} \mathrm{C}\right)$, outside relative humidity $\left(R H_{0}, \%\right)$; and the maximum heat fluxes $\left(\mathrm{W} \mathrm{m}^{-2}\right)$ for the summer months (June-September) resulting from the 4 modelled scenarios (2080s). Cooling strategies listed in Section 2.3

\begin{tabular}{|ccccccc|}
\hline \multirow{2}{*}{ Location } & \multirow{2}{*}{$T_{\mathrm{o}}$} & \multirow{2}{*}{$H R_{\mathrm{o}}$} & \multicolumn{4}{c|}{ Cooling pad system- } \\
\cline { 4 - 6 } & & & 3.1 & 3.2 & 3.3 \\
\hline \multirow{2}{*}{ Madrid } & 18.64 & 48.87 & -244.81 & -386.96 & -511.65 \\
& \pm 1.34 & \pm 4.01 & \pm 26.95 & \pm 37.24 & \pm 46.26 \\
\multirow{3}{*}{ London } & 12.95 & 73.84 & -39.65 & -97.04 & -147.31 \\
& \pm 1.18 & \pm 5.70 & \pm 19.72 & \pm 27.69 & \pm 34.78 \\
\hline
\end{tabular}

ventilation can maintain the suitable temperature only in the most favourable scenarios ( 1 and 2). The cooling pad system can supply the adequate temperature in all future scenarios. In the baseline scenario, the relative humidity of these locations is so high that the evaporative systems have low efficiency; in the 2080s scenarios, the reduction in relative humidity increases the efficiency of this type of system.

A complete set of calculations was carried out with an increase in the humidity ratio of $10 \%$ in the 2080 s scenarios, with respect to the baseline scenario. In Table 4 , the results for London (northern location) and Madrid (southern location) are shown. This batch of simulations did not show any change affecting the cooling technologies with respect to the rest of the simulations, performed with the assumption of a constant humidity ratio (Table 3). Despite decreasing the efficiency of the cooling pad due to the higher relative humidity, these strategies still provided a negative heat flux.

In light of the above, the most suitable cooling strategy for southern locations (Madrid, Milan, Athens) is 3.1 (cooling pad; $\mathrm{N}=20 \mathrm{~h}^{-1}$ ), both in the baseline and future scenarios. In contrast, important changes in cooling technologies will be needed in northern Europe in the same type of buildings: Stuttgart should change from Strategy 2.1 (forced ventilation; $\mathrm{N}=20 \mathrm{~h}^{-1}$ ) to 3.1 in the future; London and De Bilt should change from Strategy 1.3 (natural ventilation, $\mathrm{N}=15 \mathrm{~h}^{-1}$ ) to 3.1 . The same methodology can be applied to the cooling process of other types of agricultural buildings.

\section{CONCLUSIONS}

The study shows the methodology that can be applied to evaluate changes in cooling technologies of agricultural buildings derived from different scenarios of global climate change. Four 2080 scenarios were analysed for 6 European locations, using as a case study fattening pig farms and 3 cooling technologies: natural and forced ventilation, and cooling pads.
Differences among scenarios were small. No changes in cooling technologies were necessary in the Mediterranean Basin; cooling pads were necessary (and efficient enough) both in the present and future scenarios for an adequate climatisation. The conclusion was the same for all future scenarios studied.

In northern Europe, results were different depending on the future scenario studied. However, most scenarios indicated that cooling pads will be needed in fattening pig farms in the 2080 s, while ventilation is efficient enough in the baseline scenario. The critical point for this change in cooling technologies in northern Europe (for this type of farm) was obtained for a temperature increase of about $3^{\circ} \mathrm{C}$. The economic consequences will be important for this sector, as the costs associated with cooling pads are much higher than the costs of ventilation.

Acknowledgements. We used climate data provided by the EU-FP6 MILLENNIUM project (http://geography.swan.ac. $\mathrm{uk} / \mathrm{millennium} / \mathrm{index} \cdot \mathrm{htm}$ ) and the ECA\&D project (http:// eca.knmi.nl). V.V. acknowledges financial support from the Spanish Ministry of Education (MEC) through grant FPU AP2007-00432.

\section{LITERATURE CITED}

Blanes V, Pedersen S (2005) Ventilation flow in pig houses measured and calculated by carbon dioxide moisture and heat balance equations. Biosyst Eng 92:483-493

Christensen JH, Timothy RC, Rummukainen M, Amanatidis G (2007) Evaluating the performance and utility of regional climate models: the PRUDENCE project. Clim Change 81:1-6

CIGR (Commission International du Genié Rural) (2002) Climatization of animal houses. Heat and moisture production at animal and house levels. 4th Report of Working Group. Research Centre Bygholm, Horsens

CIGR (2006) Animal housing in hot climates: a multidisciplinary view. CIGR Section II Working Group in cooperation with EurAgEng, Campinas

Ciscar JC, Iglesias A, Feyen L, Goodess CM and others (2009) Climate change impacts in Europe. Final report of the PESETA research project. EUR24093EN. JCR Sci Tech Rep

Cooper K, Parsons DJ, Demmers T (1998) A thermal balance model for livestock buildings for use in climate studies. J Agric Eng Res 69:43-52

Forman S, Hungerford N, Yamakawa M, Yanase T, Tsai HJ, Joo YS, Yang DK, Nha JJ (2008) Climate change impacts and risks for animal health in Asia. Rev Sci Tech Off Int Epizoot 27:581-597

> García JL, De la Plaza S, Navas LM, Benavente RM, Luna L (1998) Evaluation of the feasibility of alternative energy sources for greenhouse heating. J Agric Eng Res 69: 107-114

Haeussermann A, Hartung E, Jungbluth T, Vranken E, Aerts JM, Berckmans D (2007) Cooling effects and evaporation characteristics of fogging systems in an experimental piggery. Biosyst Eng 97:395-405

IDAE (Instituto para la Diversificación y Ahorro de la Energía) (2005). Ahorro y eficiencia en instalaciones ganaderas. IDAE, Madrid 
Iglesias A, Rosenzweig C, Pereira D (2000) Agricultural impacts of climate change in Spain: developing tools for a spatial analysis. Glob Environ Change 10:69-80

IPCC (Intergovernmental Panel on Climate Change) (2000) Special report: emission scenarios. Cambridge University Press, Cambridge

IPCC (2007) Contribution of Working Groups I, II and III to the Fourth Assessment Report of the Intergovernmental Panel on Climate Change. IPCC, Geneva

Kittas C, Bartzanas T, Jaffrin A (2003) Temperature gradients in a partially shaded large greenhouse equipped with evaporative cooling pads. Biosyst Eng 85:87-94

Klein Tank AMG, Wijngaard JB, Können GP, Böhm R and others (2002) Daily dataset of 20th century surface air temperature and precipitation series for the European Climate Assessment. Int J Climatol 22:1441-1453

Mader TL, Davis MS (2004) Effect of management strategies on reducing heat stress of feedlot cattle: feed and water intake. J Anim Sci 82:3077-3087

Mínguez MI, Ruiz-Ramos M, Díaz-Ambrona CH, Quemada M, Sau F (2007) First-order impacts on winter and summer crops assessed with various high-resolution climate models in the Iberian Peninsula. Clim Change 81:343-355

Nienaber JA, Hahn GL (2007) Livestock production system management responses to thermal challenges. Int J Biometeorol 52:149-157

Olesen JE, Bindi M (2002) Consequences of climate change for European agricultural productivity, land use and policy. Eur J Agron 16:239-262

Olesen JE, Carter TR, Díaz-Ambrona CH, Fronzek S and others (2007) Uncertainties in projected impacts of climate change on European agriculture and terrestrial ecosystems based on scenarios from regional climate models. Clim Change 81:123-143

Submitted: March 9, 2010; Accepted: July 30, 2010
Panagakis P, Axaopoulos P (2008) Comparing fogging strategies for pig rearing using simulations to determine apparent heat-stress indices. Biosyst Eng 99:112-118

Rötter R, van de Geijn RS (1999) Climate change effects on plant growth, crop yield and livestock. Clim Change 43: 651-681

Parry ML, Rosenzweig C, Iglesias A, Livermore M, Fischer G (2004) Effects of climate change on global food production under SRES emissions and socio-economic scenarios. Glob Environ Change 14:53-67

Romero A, García JL, Benavente RM, Luna L, Paramés E (2002) Sistemas de refrigeración de bajo coste en invernaderos (Greenhouse low-cost cooling systems). Horticultura 159: 28-33

Schauberger G, Piringer M, Petz E (2000) Steady-state model to calculate the indoor climate of livestock buildings, demonstrated for finishing pigs. Int J Biometeorol 43:154-162

Seginer I (2002) The Penman-Monteith evapotranspiration equation as an element in greenhouse ventilation design. Biosyst Eng 82:423-439

Semenov MA, Stratonovitch P (2010) Use of multi-model ensembles from global climate models for assessment of climate change impacts. Clim Res 41:1-14

Singh AK, Singh H, Singh SP, Sawhney RL (2002) Numerical calculation of psychrometric properties on a calculator. Build Environ 37:415-419

Thom EC (1959) The discomfort index. Weatherwise 12:57-59

> Thornton PK, Van de Steeg J, Notenbaert A, Herrero M (2009) The impacts of climate change on livestock and livestock systems in developing countries: a review of what we know and what we need to know. Agric Syst 101: $113-127$

Willits DH (2003) Cooling fan-ventilated greenhouses: a modelling study. Biosyst Eng 84:315-329

Proofs received from author(s): September 1, 2010 